\title{
Lake shore deterioration, reed management and bank restoration in some Central European lakes *
}

\author{
Wolfgang Ostendorp ${ }^{\text {a, }}$, Christoph Iseli ${ }^{b}$, Manfred Krauss ${ }^{c}$, \\ Priska Krumscheid-Plankert ${ }^{d}$, Jean-Louis Moret ${ }^{e}$, Maurice Rollier ${ }^{\mathrm{f}}$, \\ Ferdinand Schanz ${ }^{\mathrm{g}}$ \\ ${ }^{a}$ Limnologisches Institut der Universität Konstanz, Postfach 5560, D-78434 Konstanz, Germany \\ ${ }^{b}$ Th. Kocher Str. 7, CH-2502 Biel / Bienne, Switzerland \\ ${ }^{c}$ Schloßstraße 22, D-14059 Berlin 19, Germany \\ ${ }^{d}$ Limnologisches Institut der Universität Konstanz, Postfach 5560, D-78434 Konstanz, Germany \\ ${ }^{c}$ Musée et Jardins Votaniques Cantonaus, Avenue de Cour 14bis, CH-1007 Lausanne, Switzerland \\ ${ }^{\mathrm{f}}$ Groupe d'étude et de gestion, Champ Pittet, CH-1400 Cheseaux-Noréaz, Switzerland \\ ${ }^{\mathrm{g}}$ Hydrobiologisch-Limnologische Station der Universität Zürich, Seestraße 187, CH-8802 Kilchberg, \\ Switzerland
}

\begin{abstract}
The causes of lakeshore deterioration and reed decline are concisely summarised, and demonstrated with examples of seven Central European lakes (Germany: Havel lakes, Lake Constance-Untersee, Lake Constance-Obersee; Switzerland: Lake Zürich, Lake Biel, Lake Neuchâtel, Lake Geneva). The main causes are assumed to be bank erosion, lake eutrophication, mechanical damage to the reeds, and recreational activities. Countermeasures can be grouped into: reed protection against mechanical load (fences), wave dissipative constructions (refilling of substrate, brushwood fascine), nutrient export from the reeds (winter mowing), and supplementary measures (reed plantations, prohibition of access for the public). Favourable issues and undesired results are discussed. It is stated that there is a need for fundamental research and scientific surveillance of the restoration measures to avoid ill effects in the future.
\end{abstract}

Keywords: Phragmites australis; Bank erosion; Reed die-back; Winter mowing of reeds; Reedswamp; Restoration

\footnotetext{
${ }^{*}$ Parts of this paper have been presented at the IV International INTECOL Wetlands Conference, Columbus, Ohio, USA, 13-18 September, 1992.

* Corresponding author.
} 


\section{Introduction}

The lakeshores of Central Europe are among the most intensively occupied elements of the landscape. They have been built over by settlements, promenades, sports-grounds, rubbish dumps and used for recreational purposes such as bathing beaches, week-end houses and boating areas. They suffer from attacks by coypu and muskrat, animals which have been introduced by man for his fur. Lake water level changes, underwater gravel pits, walls and dams protecting the shore and the wake of cargo boats greatly influence the stability of the land-water transition zone as well as the reedbeds themselves. Bedload input into the lakes is altered by reservoirs in the hinterland, by embankments of rivers, and by the construction of new inlets, inactivating old deltas.

Bank erosion and reed decline are expressions of these interconnected changes which could be encountered within many parts of Europe (Ostendorp, 1989). From the 1960 s onward, the reed decline in many lakes reached such an order of magnitude that the authorities were stirred to action. Many measures to protect the reed, to plant new reedbeds, and to defend the natural shoreline from erosion were initiated. More than ten million German marks (DM) were spent in Switzerland and West Germany alone. It seems therefore reasonable to critically summarise the present situation, with the objective of contributing to an enhanced discussion between civil engineers, limnologists, and the authorities about how reedbed plantations and natural shore restoration works can be optimised.

\section{Reed decline and bank erosion: causes and consequences}

Reed decline has been documented at ca. 45 European lakes (Fig. 1); the cases are concentrated where there has been intensive mapping of the littoral vegetation. Hence, one may conclude that many cases of reed 'die-back' remained undetected until now because of lack of research.

The literature points to a multiplicity of (potential) causes which can be grouped into six classes (Ostendorp, 1989):

1. Direct destruction (land reclamation, recreational activities, etc.);

2. mechanical damage (wave action due to wind and cargo boats, floating rubbish, drifting wood, wash of filamentous algae, etc.);

3. grazing by wild animals (Greylag Geese Anser anser, Mute Swans Cygnus olor, Coots Fulica atra, Coypus Myocastor coypus and Muskrats Ondatra zibethicus), and cattle, and destruction by pests;

4. water and sediment quality (lake eutrophication and sapropel formation in the reedbeds);

5. lake level regulation, flooding, and bank erosion; and

6. replacement by other plants, especially shading by bushes and replacement by the reedmace (Typha sp.) and the reed grass (Glyceria maxima).

However, the significance of these factors is a matter of continuing controversy. 


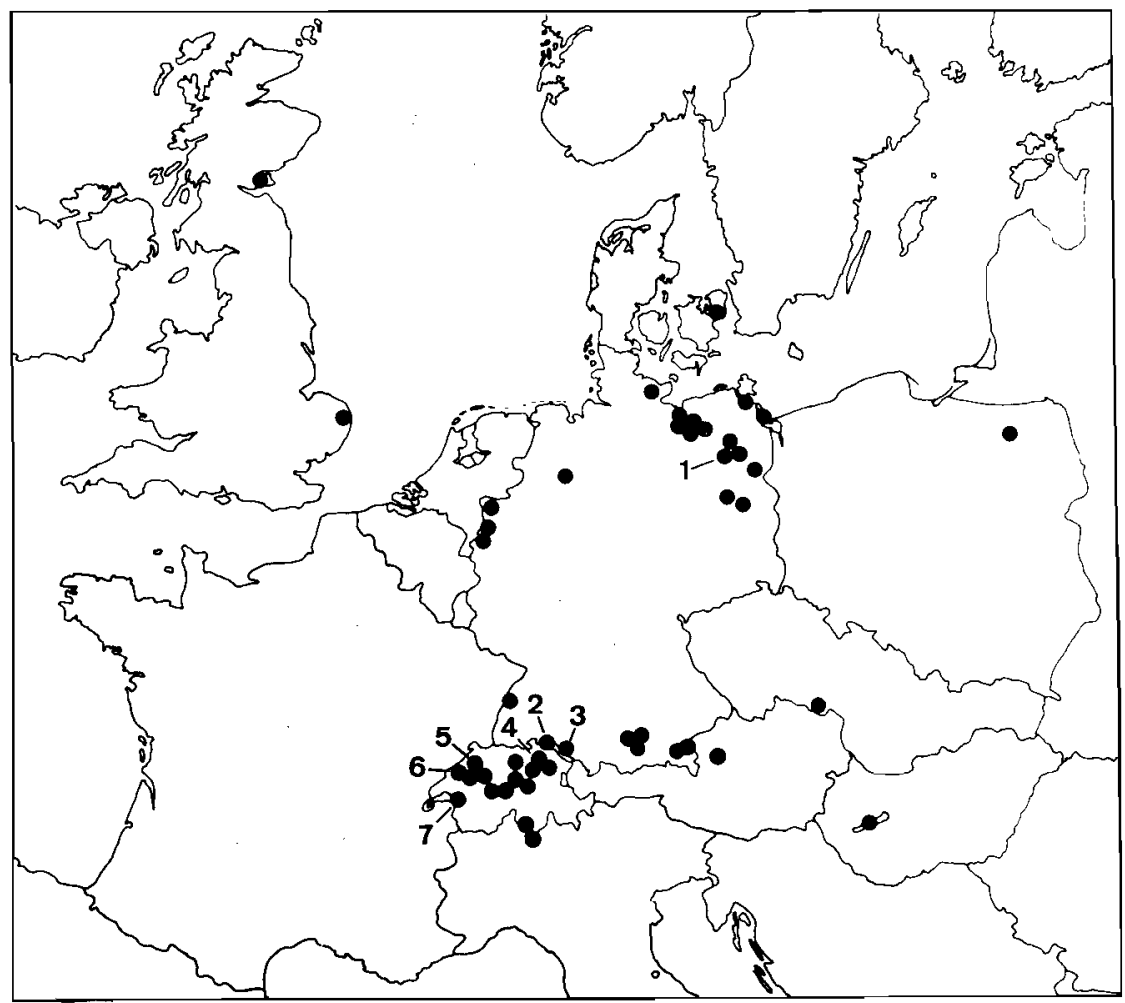

Fig. 1. Reed decline in European Lakes (arrows: lakes dealt with in this paper; 1, Havel; 2, Lake Constance-Untersee; 3, Lake Constance-Obersee; 4, Lake Zürich; 5, Lake Biel; 6, Lake Neuchâtel; 7, Lake Geneva).

The reed decline is the first link of a chain which may lead to a deterioration of the littoral biocoenosis, comprising:

1. Lack of bank protection creating opportunities for erosion and drift of littoral sediments into the sublittoral offshore, and for forming sapropel banks in wind protected bays;

2. uprooting of nearshore trees and bushes, and extinction of the submerged vegetation;

3. disappearance of bird species like Great Reed Warbler (Acrocephalus arundinaceus), Little Bittern (Ixobrychus minutus), Little Grebe (Podiceps ruficollis) and Purple Heron (Ardea purpurea); and

4. reduction in the size of the population of phytophilic fish species like Pike (Esox lucius), Tench (Tinca tinca), Carp (Cyprinus carpio), Rudd (Scardinius erythrophthalmus) and others.

One may assume that other aspects of littoral community structure, food web, microbial activity and carbon and nutrient turnover are also affected, but scientific investigations are lacking. 


\section{Case studies}

In the following sections seven examples from large lakes in Europe are given to illustrate the symptoms and the causes of decline, and the measures for protecting and maintaining healthy lake shore environments.

\subsection{Havel (Berlin)}

The Havel is a typical lowland river with large lake-like widenings. The water level of the Upper Havel is relatively constant but the water level of the Lower Havel fluctuates by $1 \mathrm{~m}$ in a year on average. The water is polytrophic with up to $0.29 \mathrm{mg} \mathrm{l}^{-1}$ and $0.35 \mathrm{mg} \mathrm{l}^{-1} \mathrm{P}_{\text {tot }}\left(1.7\right.$ and $\left.4.3 \mathrm{mg} \mathrm{l}^{-1} \mathrm{~N}_{\text {tot }}\right)$ in the Upper Havel and in the Lower Havel, respectively. The dominant species in the reedbelt is the common reed (Phragmites australis), mixed with the lesser reedmace (Typha angustifolia) on the muddy substrates.

Before 1962 wide reedbelts covered more than $40 \%$ of the shoreline's length, but in 1987 nearly $70 \%$ (i.e., $26 \mathrm{~km}$ of shoreline) of the reed have been destroyed (Sukopp and Markstein, 1989). However, wide reeds without a sign of damage persist at some places.

Eutrophication and wave action are thought to be the main causes of the reed decline in the Havel:

1. The nutrient increase leads to a mass development of Cladophora, a filamentous algae, damaging the reed stalks mechanically (Krauss, 1979).

2. The wave energy is increased by cargo ships. Ship induced waves, $30-50 \mathrm{~cm}$ high, surge against the shore, eroding the bank, washing out the organic detritus and uprooting the isolated Phragmites tussocks.

Additional factors are:

1. the intensive grazing of muskrats (Krauss, 1990);

2. nearshore groundwater wells, which are suspected of causing a landside dry-up (Wöbbecke and Ripl, 1990);

3. mechanical damage by trampling, bathing, anchoring of sporting boats;

4. direct destruction of reedbeds by land reclamation and shore protection works; and

5. mechanical damage to the littoral plant communities by recovery of ammunition from the Second World War, which was dredged for by large electromagnets.

One further stress, not as yet discussed, is the impact of drifting ice. Ship-induced waves cause a vertical uplift of several decimeters of the nearshore ice-floe, thereby dislodging the rhizome anchoring, and uprooting the reed tussocks.

An intense campaign for reed protection and lakeshore restoration was started in 1980 by the Senatsverwaltung für Stadtentwicklung und Umweltschutz (Federal Authority for Urbiculture and Conservation of Nature). The objective was to preserve or to reconstruct parts of a bare riparian landscape, diverse and rich in species, as it existed at the beginning of the century. Therefore it was necessary to stop the detrimental effects of waves on the remaining reed by using the following: 


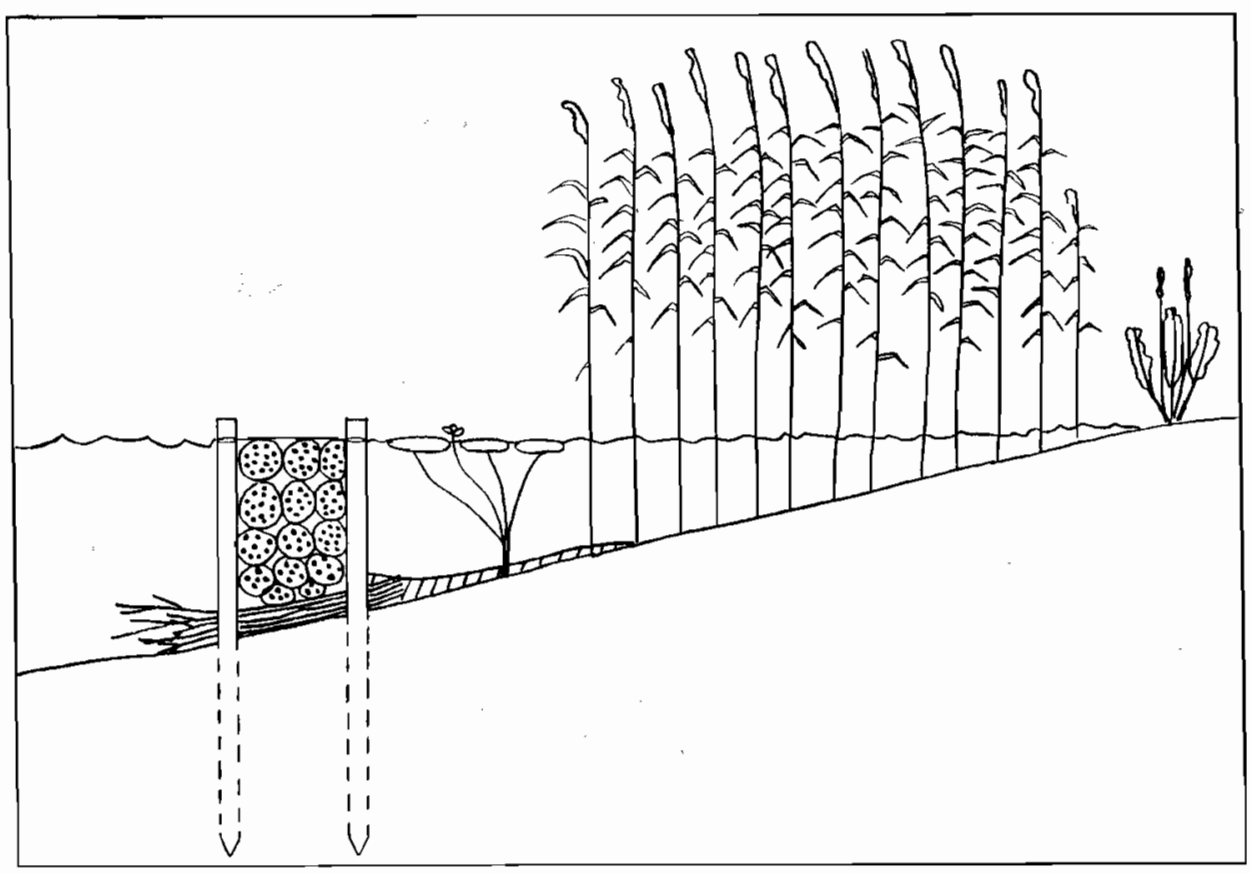

Fig. 2. Sectional drawing of an underwater wall (for explanation see text).

1. The maximum speed of sporting boats and cargo ships was limited to $24 \mathrm{~km} \mathrm{~h}^{-1}$ and $12 \mathrm{~km} \mathrm{~h}^{-1}$, respectively, bringing some relief to the reeds.

2. Field experiments were performed with several types of breakwaters such as stone dams, palisades and others. Double pile rows with a fixed brushwood fascine between them (in German: 'Lahnung') parallel to the shoreline have been proved to be best adapted to the special situation at the Havel (Fig. 2). The constructions were built in a water depth of ca. $1 \mathrm{~m}$, reaching from the ground to the mean water level, at a distance of about $30 \mathrm{~m}$ from the shore. They dissipated the wave energy, but a partial exchange of water between the calm inner zone and the open lake was allowed. Waterfowl and fishes could pass through gaps at intervals of $20-30 \mathrm{~m}$. Up to now approximately $8 \mathrm{~km}$ of shoreline has been protected in this manner (Fig. 3).

3. Plantations of Phragmites australis, Typha angustifolia, Schoenoplectus lacustris and Acorus calamus were established wherever a natural reedbelt was lacking. It was experienced that $T$. angustifolia and $A$. calamus were the best for taking root, whereas the plantations with $P$. australis showed only a weak growth or failed. However, after some time Phragmites invaded spontaneously, and will probably dominate in these mixed stands one day. Most success was achieved in shore sections, which were not affected by the deep groundwater pumping stations, and when a new planting bed was formed by a new layer of sand. The trend in development of the remaining natural reed stands within the protected 


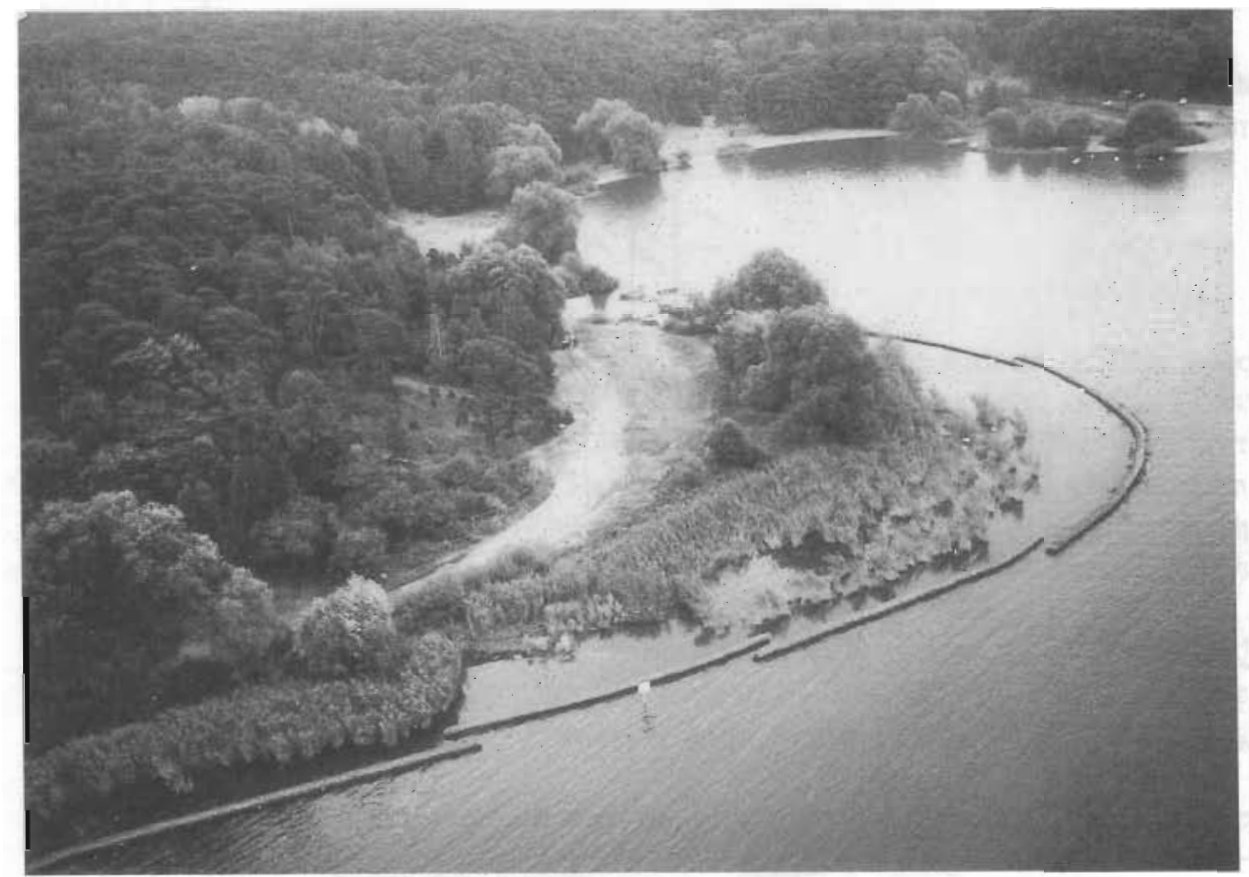

Fig. 3. Aerial view of an underwater wall; the reed stands disintegrated into bulks are evenly discernible.

area is not clear-cut: disintegrated reed stands went on declining; others, however, stabilise and progress anew.

The construction of the pile rows with fascine fillings together with the planting of reeds cost ca. 500-1000 DM per running meter of shoreline. The eroded shore sections, which had been protected with massive stone facings and sheet pilings, can scarcely be restored.

\subsection{Lake Constance-Untersee}

Lake Constance-Untersee is an eutrophic perialpine lake with high annual water level fluctuations (ca. $1.9 \mathrm{~m}$ on average) and large gently sloped shore platforms. Fifty-four percent of the German shore line is covered with Phragmites-reeds. At the beginning of the 1970s nutrient loads increased rapidly, reaching maximum levels of $90-100 \mu \mathrm{g} \mathrm{P}^{-1}$ (soluble turnover phosphorus) around 1980. Since then soluble phosphorus has dropped to below $50 \mu \mathrm{g} \mathrm{P} \mathrm{I}^{-1}$.

In the first half of the century the reedbelts expanded to the mean low water bathometric line, and in the $1950 \mathrm{~s}$ a maximum of 380 hectares was reached (German territory only) (Ostendorp, 1990b). A few years later the decline began. The losses, initially restricted to the landward edge were due to direct destruction (land reclamation for recreational activities, construction of buildings, etc.). A 


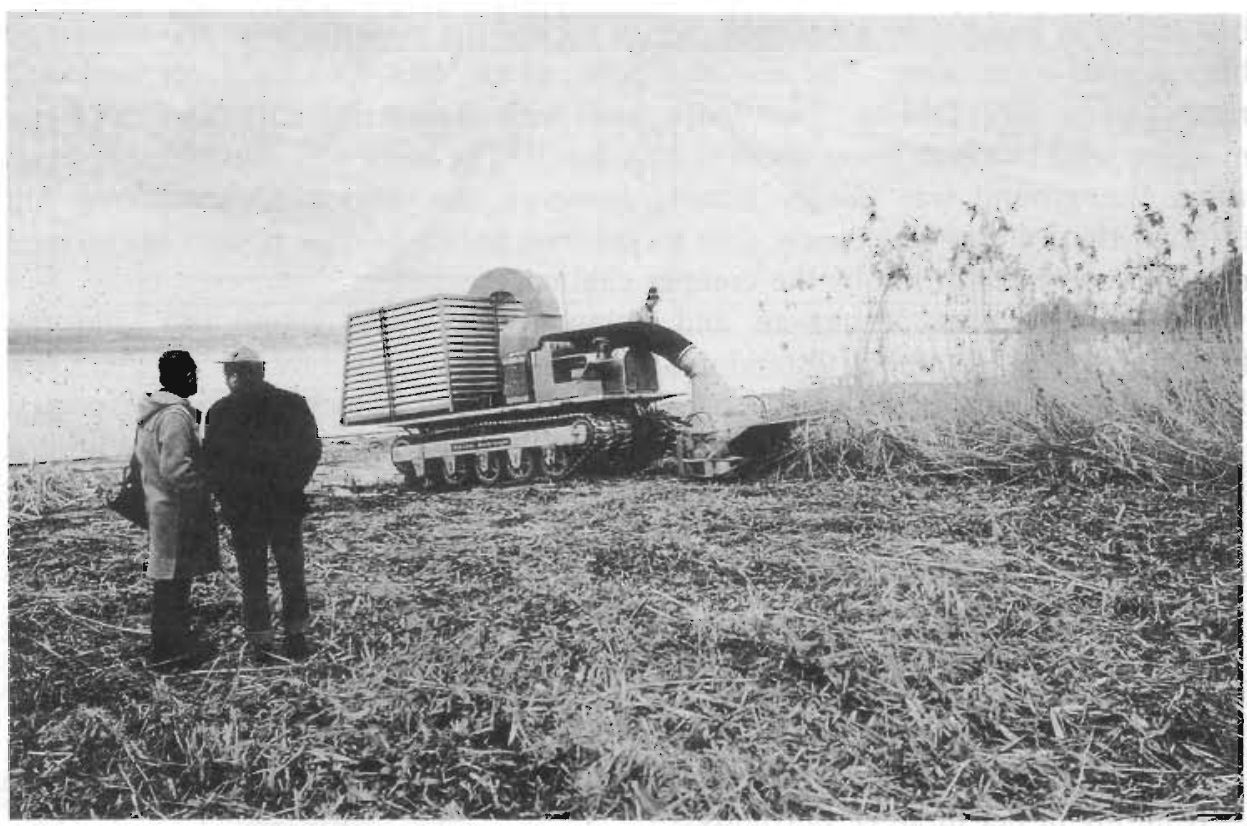

Fig. 4. Mowing vessel used at Lake Constance-Untersee with a mowing-chaffing-sucking device at the front.

dramatic die-back occurred between 1965 and 1980 when $37 \%$ of the reedbeds below the mean water level line were lost. The die-back stopped at the beginning of the $1980 \mathrm{~s}$, and since then the lakeside reeds have slowly progressed at some sites (Pier et al., 1990).

The hypothesis of Schröder (1979, Schröder, 1987) about the causes of the reed decline in Lake Constance-Untersee established the concept of the reed maintenance measurements. The die-back was suspected to have been initiated by the eutrophication of Lake Constance since the 1960s. The improved nutrient supply led to an increased stalk density, and to a weakening of the breaking resistance of the stalk. The broken stalks hindered the water exchange with the open littoral, and organic matter and nutrients accumulated in the reedbed. During the decomposition of the organic matter oxygen depleted in the overlaying water, and reduced substances $\left(\mathrm{H}_{2} \mathrm{~S}, \mathrm{CH}_{4}\right)$ were released, which were thought to be toxic to Phragmites roots. The wash of filamentous algae exacerbated these detrimental effects.

The idea of the reed maintenance measures was to interrupt the steady accumulation of nutrients by winter mowing and removing the dead stalks from the reedbed. Field tests ran between 1979 and 1983. The mowing was done by different types of caterpillar vessels with an interchangeable mowing and chaffing device at the front (Fig. 4). The chaff-cutter consisted of a rotatory roller to which Y-shaped knifes were attached by shackles. It was best suited for use in dense reed thickets and shrubberies. The chaffed straw and the litter was removed from the 
bed either by hand or by a machine, which sucked the material from the roller and blew it into a container. The cost was between ca. $4000 \mathrm{DM} \mathrm{ha}^{-1}$ for landward reeds and ca. $5000 \mathrm{DM} \mathrm{ha}^{-1}$ for dense reeds with stout stalks. The capacity of one machine with two hands was about 0.7 ha day ${ }^{-1}$. The work was usually carried out when the ground was deeply frozen; however, the caterpillar sometimes fell through the ice and was barely able to get free under its own power. Many reed rhizomes were destroyed by the creeper chains.

The development of mowed and unmowed beds was monitored, and the following results obtained (Ostendorp, 1987):

1. The winter mowing did not decrease the stalk density which was to be expected according to Schröder's hypothesis, but instead led to an increase. Where a diminution occurred, this was the consequence of severe damage to the young shoots by waves and washes.

2. The resistance to mechanical damage of the reeds was lowered: the wall tissue of the stem was weakened and the stand structure developed unfavourably, as the stout primary shoots were replaced by weak and slender secondary shoots.

3. The concentrations of organic matter, $P_{\text {tot }}$ and $N_{\text {tot }}$ in the sediment surface layer increased in many mown beds. It was noticed that nutrient rich calcareous muds were mobilised in the sublittoral and easily washed into the mown reeds, resulting in net input of nutrients.

4. The reed area did not increase, but decreased by a total of 2.9 hectares (including ca. 1.3 ha due to direct destruction of rhizomes by the creeper chains, more than 1.4 ha due to mechanical damage by wave-forced drifting matter and algal flotsams). Mechanical impacts were shown to have more serious consequences for mowed than for untreated reeds.

Hence, it is concluded that in Lake Constance-Untersee winter mowing does not contribute to the health and preservation of lakeside Phragmites reeds, and it is not suitable for stopping the die-back of the reeds (Fig. 5). On the contrary, one has to face continuous losses of the reed bed area, even though damage does not occur every year and does not affect every site.

\subsection{Lake Constance-Obersee}

Lake Constance-Obersee is the deep 'upper lake' of Lake Constance (area 476 $\mathrm{km}^{2}$, max. depth $252 \mathrm{~m}$, mean depth $100 \mathrm{~m}$ ). Generally, the littoral zone is relatively narrow compared to Lake Constance-Untersee. In its natural state, the Obersee was a typical oligotrophic pre-alpine lake with low concentrations of nutrients; from ca. 1960 until $1980 \mathrm{PO}_{4}-\mathrm{P}$ (spring turnover concentrations) increased to a maximum of $87 \mu \mathrm{g}^{-1}$; since then the $\mathrm{PO}_{4}-\mathrm{P}$ load dropped to ca. 40 $\mu \mathrm{g}^{-1}$.

Similar to Lake Constance-Untersee Phragmites belts at Obersee extended far lakewards in the 1930s and 1940s. The maximum extension though is unknown for most places. An analysis of reed regression by interpretation of vertical aerial photographs from 1967, 1978, and 1984 shows a total loss of at least 15 hectares of submerged reed beds (i.e., $50 \%$ of the area of 1967, shoreline in the state of 


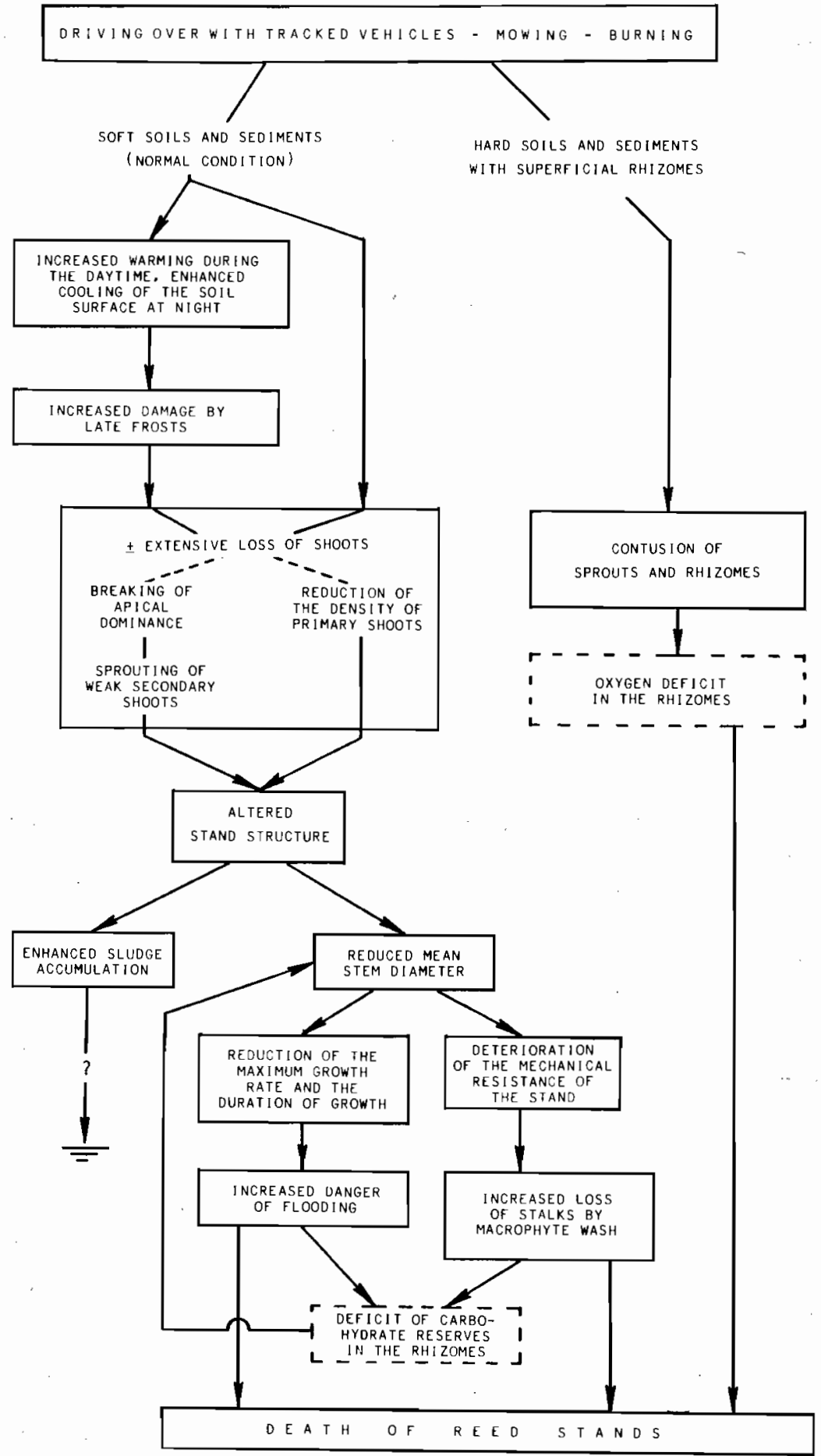

Fig. 5. Flow diagramm showing the detrimental consequences of winter mowing of reeds at Lake Constance-Untersee. 


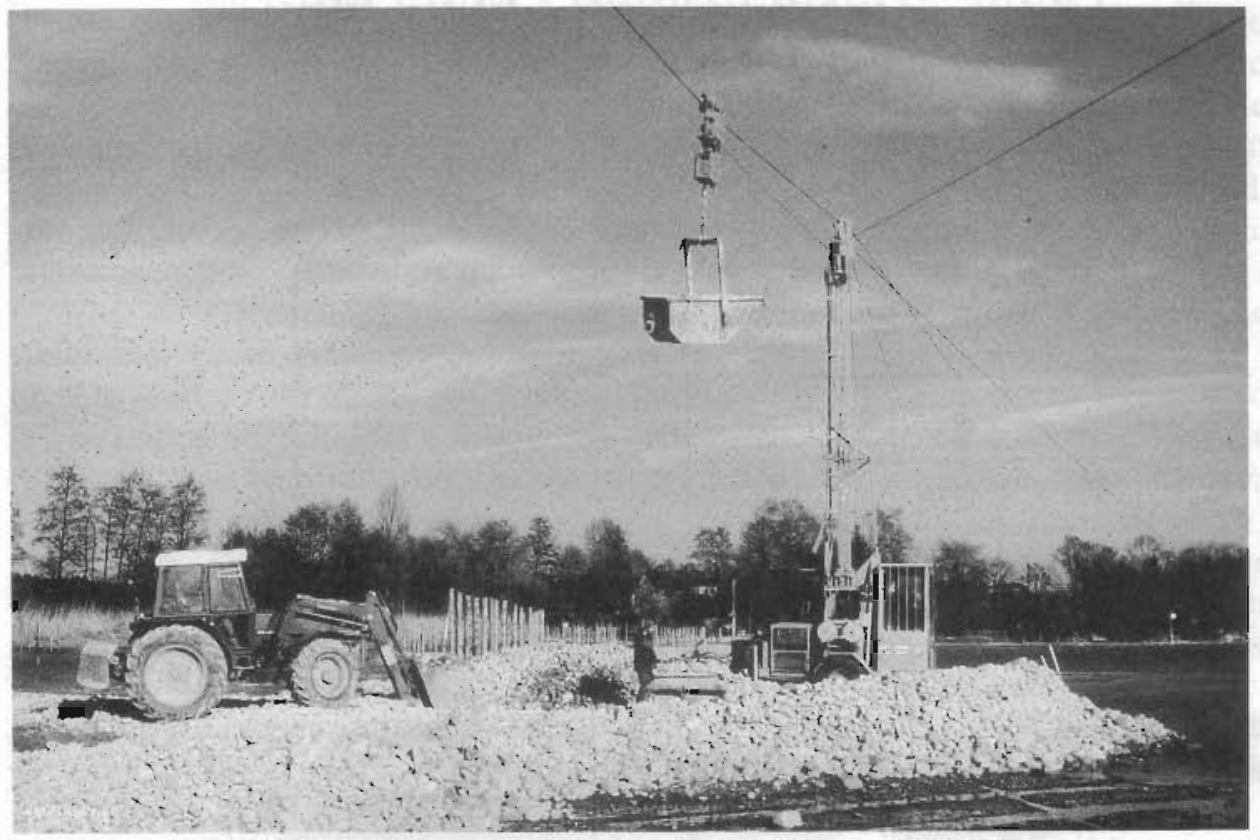

Fig. 6. The stone dam is constructed as a lakeward boundary for the substrate refilling; here the stones are transported by aerial cableway to the shore.

Baden-Württemberg only) (Krumscheid et al., 1989). Regression occurred predominantly between 1967 and 1978. Mostly west-and southwest-exposed stands were severely damaged. In more recent years a slow progression was under way at most sites.

In Lake Constance-Obersee mechanical stress by waves loaded with cultural debris, algal and macrophytal mats and driftwood as well as bank erosion affect lakeside reed to a great extent (Hagenmeyer and Krumscheid-Plankert, 1990).

In 1983 the local authorities began with restoration projects at some highly endangered lakeside reed stands. A five-year project was initiated 1987 in order to find an optimal technique to save and restore aquatic reed belts, financed by the Bundesministerium für Umwelt, Naturschutz und Reaktorsicherheit (Federal Ministry for the Environment, Conservation of Nature and Nuclear Safety). Three different restoration methods are being tested: at three sites a shallow refilling of substrate is heaped up (by aerial cableway or by building machines) to compensate for the erosion. A stone dam is constructed as a lakeward boundary at a distance of about $30 \mathrm{~m}$ from the shore and in the altitude of the mean water level (Fig. 6). After refilling with substrate the detrimental effects of waves on the remaining reed are reduced: at high water levels energy is lowered by friction on the (new) littoral bottom in front of the reed stand (Fig. 7). Different substrate types are tested. Two other methods are designed to promote accumulation of sediment by longshore currents. In one case sedimentation lozenges were constructed with coir 


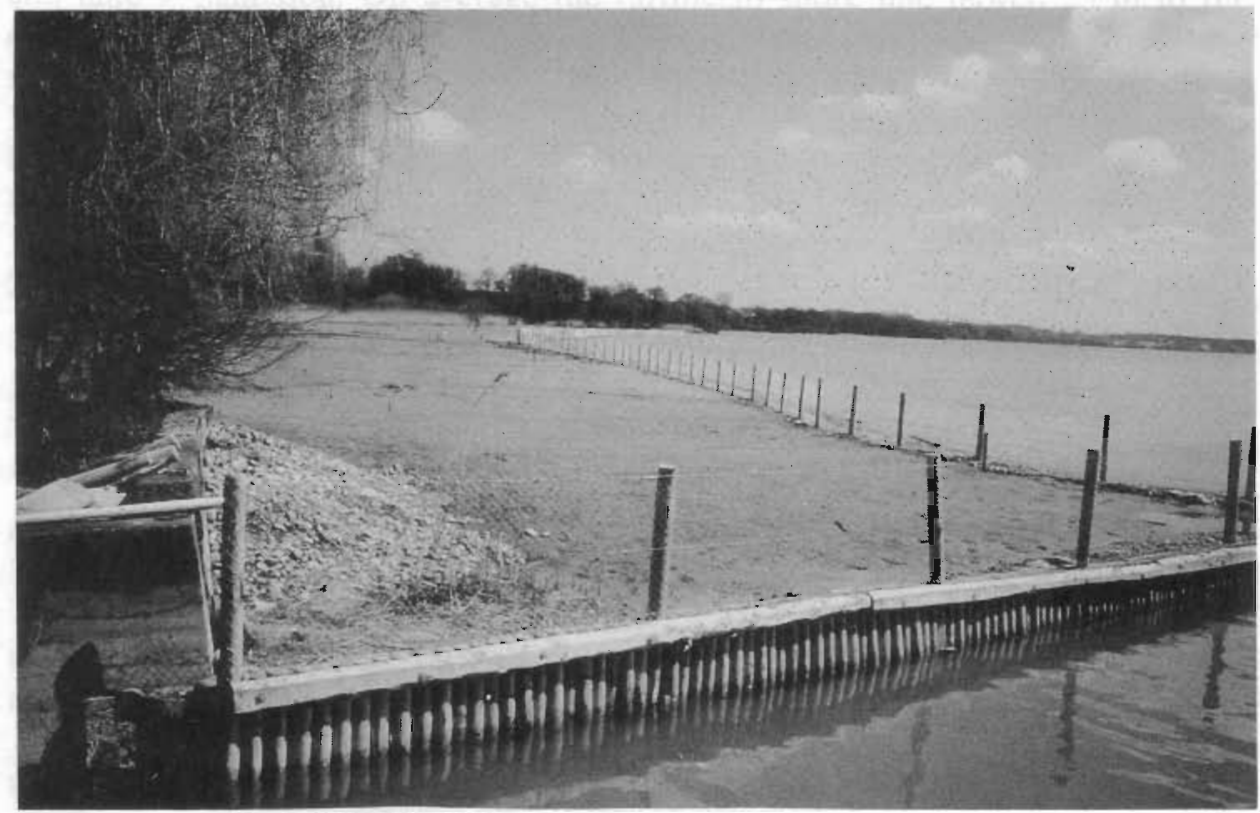

Fig. 7. View of the test area Lipbachmündung (method: stone dam and shallow refilling) just after completing the restoration works in April 1987 and before rising of the water level.

fabric in front of the reed stand (Fig. 8). The caskets are 15 to $30 \mathrm{~cm}$ high and are built into the sediment by hand. They are effective for 2 to 3 years until the material decays. The method is built on a small scale compared with the others, and forms a gentle restoration. In the other case stone groynes are constructed to promote sedimentation in the calm areas.

In addition, attempts are made to plant reed beds where they once had been growing, the intention being to close gaps and create continuous stands. The difficulty at Lake Constance is the annually fluctuating water level: lowest (in February) and highest water levels (in June/July) differ on average by $1.9 \mathrm{~m}$. In May and June, shoots of reed grow about $4 \mathrm{~cm}$ per day. Usually this is sufficient to keep up with the rising water level. Planted reed, however, grows only at a rate of ca. $2 \mathrm{~cm}$ per day (Krumscheid-Plankert, 1992). To improve the vitality of reed and smooth the shock effect of transplantation, the young plants are partially precultivated in basins with a constant water level, and are transferred to the lakeshore a year or two later. The pre-cultivated plants show higher growth rates.

After four years of observation, preliminary results can be presented: The method of sediment refilling behind a dam shows good stability, although it requires a lot of material and is relatively expensive (1000-1500 DM per metre of shoreline). The 'new' reed stand grows on a higher level and its ecological importance, e.g., for fish breeding or waterfowl nesting, is thought to be less than that of permanent flooded reeds. Regarding the two other methods problems of 


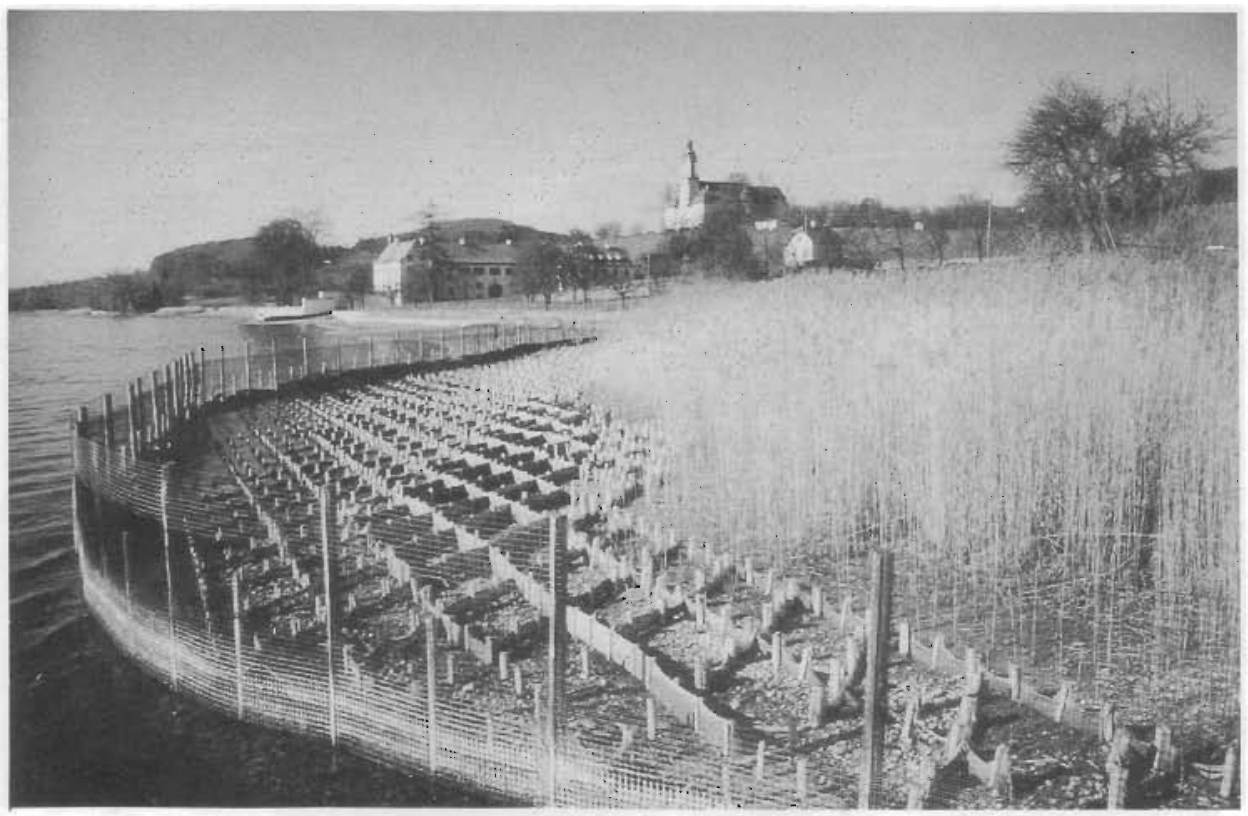

Fig. 8. Test area Obermaurach (method: sedimentation lozenges out of coir fabric at low water level).

stability arose, and together with sedimentation an undesired accumulation of filamentous algae occurred in some years. At all restoration sites a rapid lakeward progression of the remaining reed stands took place, and the plantations spread quickly.

The restoration measures designed to lower or eliminate the mechanical stress to lakeside reed belts have been successful so far. The methods presented here might be suitable for quite a number of lakes with mainly mechanically-caused damage.

\subsection{Lake Zürich}

Lake Zürich (Untersee) is a mesotrophic alpine lake. The mean annual change of water level has been reduced from $1 \mathrm{~m}$ to $0.7 \mathrm{~m}$ since 1951 by regulation (Bertschi, 1952). The total shoreline length measures $79 \mathrm{~km}$ from which $7.2 \mathrm{~km}$ are in a more or less natural condition (Lachavanne and Perfetta, 1985). More than $90 \%$ of the shoreline is protected from wave erosion by a wall of 1-2 $\mathrm{m}$ height. Land loss by erosion is therefore a problem of minor importance. Eutrophication of Lake Zürich began at the end of the last century and peaked around 1960 (90 $\mu \mathrm{g} \mathrm{P}_{\text {tot }} \mathrm{I}^{-1}, 400 \mu \mathrm{g} \mathrm{N} \mathrm{N}_{\text {inorg }} \mathrm{I}^{-1}$, 1990; $50 \mu \mathrm{g} \mathrm{P}_{\text {tot }} \mathrm{I}^{-1}$, and $830 \mu \mathrm{g} \mathrm{N}_{\text {inorg }} \mathrm{I}^{-1}$, spring turnover concentrations).

In 1850 the reed beds covered more than 90 ha (Oberli, 1990). Between 1850 and 1930 about 75 ha of the total reed area has been destroyed by accumulation 
and land reclamation. On average the (artificial) shore line moved $23 \mathrm{~m}$ to the open water. The living space of almost all aquatic plants was dramatically restricted (Schanz, 1974; Rebsamen et al., 1975; Egloff, 1977). In the period 1930 to 1979 the reeds had been restricted from 16 to 5.1 ha (Burnand, 1979) and about half of the previous 45 reedstands disappeared (Lachavanne and Perfetta, 1985). Four causes are considered to be mainly responsible for reed loss since 1930:

1. Boat traffic led to direct mechanical destruction (Klötzli, 1974).

2. Eutrophication is thought to damage the vitality of reed stalks directly by the enhanced nutrient level or mechanically by washes of filamentous green algae (mainly Cladophora) (Thomas, 1965).

3. Waterfowl such as coots and mute swans can destroy reed shoots when they are nesting in the reed belt, or by grazing on leafs or young sprouts (Schiess, 1978; Schanz, 1980).

4. The reduction of living space for reeds due to accumulation was of minor importance since 1930 .

In Lake Zürich all reed protection and restoration efforts were restricted to sites where the shallow part of the shore bank has partially remained after the accumulation measures.

Twelve out of 20 reed stands which developed well during the period 1979-88 were protected by a fence to keep the boats outside. Waterfowl, however, still gain access for breeding in large numbers.

The first plantation of reeds, organised by the Fachstelle für Naturschutz des Kanton Zürich, was set up in 1973 in a shallow bay $(120 \mathrm{~m}$ in length, shore bank 50-100 m wide) near Meilen (Fig. 9). The natural reed beds in front of shore protection walls declined between 1942 and 1960, presumably due to mechanical damage by algal wash, and only a small stretch of terrestrial reeds remained within a public park area. Seedlings of reed mace (Typha latifolia), and Phragmites plants were slipped into the mud about 10 to $15 \mathrm{~m}$ lakeward from the terrestrial reed

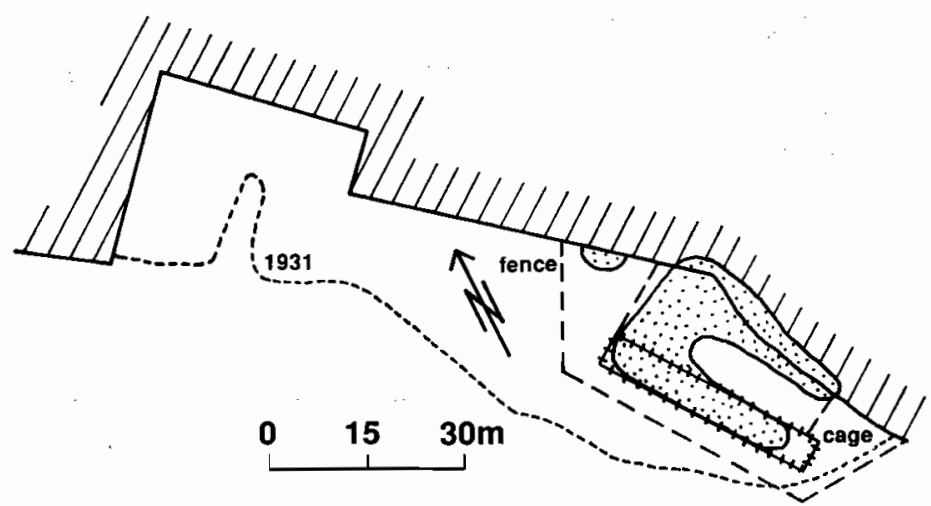

Fig. 9. Map of the reed plantation near Meilen, situtation in 1980. Dotted area, actual reed covered area; dotted line, boundary of the reed stand in 1931; dashed line, fence; right angle area with crossing, cage. 

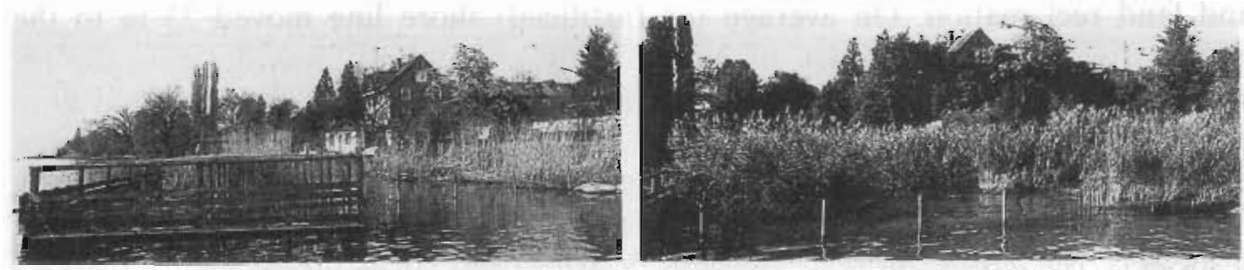

Fig. 10. View from South-East to the reed plantation near Meilen, situation in 1979 (left) and in 1989 (right). Left: Cage with the Phragmites plants inside. Its rhizomes had been pushed into the sediment by two men using a wood-pile in spring 1973. Right (1980): The planted area on the left side is connected by the recently developed reed with the terrestrial area on the right side.

stand (the planting technique is shown in Schanz (1979); Fig. 10). The seeds were derived from a marshy place north of the city of Zürich. A cage was constructed to protect the seedlings from waterfowl and boat traffic. This stand developed well and is now ca. $40 \mathrm{~m}$ long and $20 \mathrm{~m}$ large, and densely populated with Phragmites plants. In Erlenbach another Typha and Phragmites plantation was carried out in 1982 without a cage or even a fence. However, a stone barrier effective against wave action had been constructed $2 \mathrm{~m}$ in front of the reed-stand. This stand is now $80 \mathrm{~m}$ long and 5-10 m wide and consists mainly of Phragmites plants which had replaced the Typha slips by competition for light.

Around 1970 a considerable oligotrophication took place in Lake Zürich (Schanz and Thomas, 1986), reducing the mass development of filamentous green algae, and consequently improving the living conditions for Phragmites. Burnand and Küper (1988) expect an increase in total reed stand area. However, the expansion will be small because of the limitations of living space around each reed stand. These prognoses and the high costs make it rather doubtful whether new plantations of substantial size will take place in the coming years.

\subsection{Lake Biel}

Lake Biel, situated between the Swiss Midlands and the Jura Mountains, is part of an interrelated lake system (Lake Neuchâtel-Lake Biel) which was involved into a great drainage project in the 1880s (Lüdi, 1935). The mean water level of the Lake Biel was lowered by $2 \mathrm{~m}$. The formerly submerged shore platform emerged, forming a gently sloping plain of ca. 300 ha which was initially settled by the bulrush (Schoenoplectus lacustris), and, after some years with the common reed. The Phragmites reeds expanded continuously up to the midcentury (Iseli and Imhof, 1987).

From the 1920 s the nearshore zone was intensively covered with weekend-houses and embankments, destroying ca. $40 \%$ of the sites suitable for reed growth at the southern shore. In the remaining natural shore sections the waterside reeds died back from the 1950s onwards, and the reed front shifted landwards. Nothing but 'stubble fields' were left on gravel substrates, and cliffs $0.5 \mathrm{~m}$ high were carved into sandy banks. In many cases, the reeds disintegrated into isolated tussocks. The 


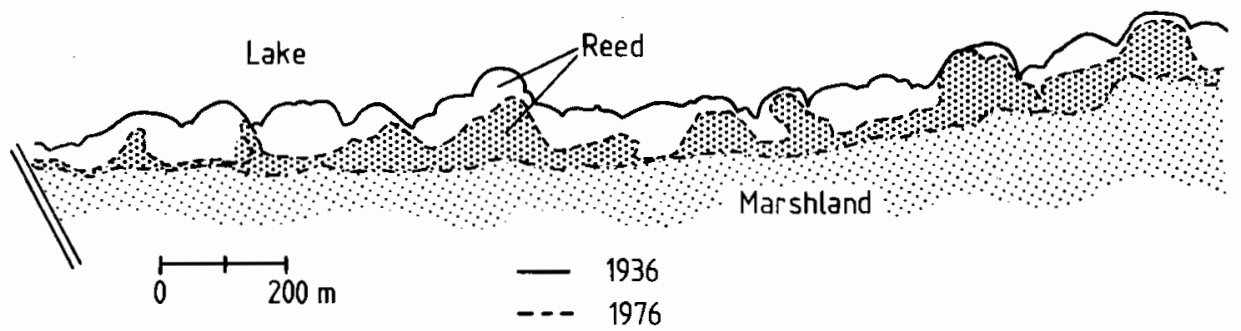

Fig. 11. Reed retreat at the northern shore of Heidenweg (Lake Biel) between 1936 and 1976 (solid line, lakeside reed front 1936; dashed line, lakeside reed front 1976; dotted line, submerged reeds in 1976; shaded area, total loss of aquatic reed beds between 1936 and 1976).

total loss of lakeside reedbeds amounted to 25 hectares (Fig. 11). The loss at the landward border of the reeds was in the same order of magnitude. At the same time the semi-aquatic reeds expanded due to silting up, giving less space for the growth of reed beds which are submerged throughout the year (Iseli, 1990).

At the Lake Biel the following factors are thought to be responsible for the die-back of lakeside reeds:

1. Embankments and land reclamations (direct destruction, preventing the establishment of reedbelt species, accentuating the bank erosion by channelling the wind induced longshore currents (Baudirektion des Kantons Bern, 1989).

2. Manipulation of the natural water level (continuous erosion of the shore platform, which is not in equilibrium with the hydrodynamic conditions of today (Huber, 1989).

3. Mechanical damage by drifting matter [trunks and other wood washed in by alpine rivers, drifting clumps of filamentous algae (Iseli, 1990].

4. Grazing by waterfowl, bathing and other recreational activities, and waves induced by sporting boats were factors of lesser significance. However, these impacts have been intensified during the last decades.

At the moment, it is not possible to quantify the relative importance of these factors. Presumably, the overall effects due to particular changes of the physical environment of the lakeside reedbeds are not always reversible, even if the growth conditions are improved.

The reed protection concept is based upon scientific findings, and instruments of policy, regional planning and bio-engineering. These means are ready to be engaged in the near future. A law of the canton of Bern obliges the communities adjacent to the lake to protect and to restore the natural banks. The work is done by a private society and financed by the cantonal government. The concept is as follows:

1. Control of causal factors: no natural shore sections are allowed by law to be covered with buildings. Bank protection measures can only be achieved by bio-engineering methods like flat-bottomed raisings or plantations of willows or brushwood fascines. The possibilities of retaining drifting wood are improved.

2. Reedbed protection: bank erosion and mechanical damage of the lakeside reeds by wave action and drifting matter is lowered by a brushwood fascine fixed 

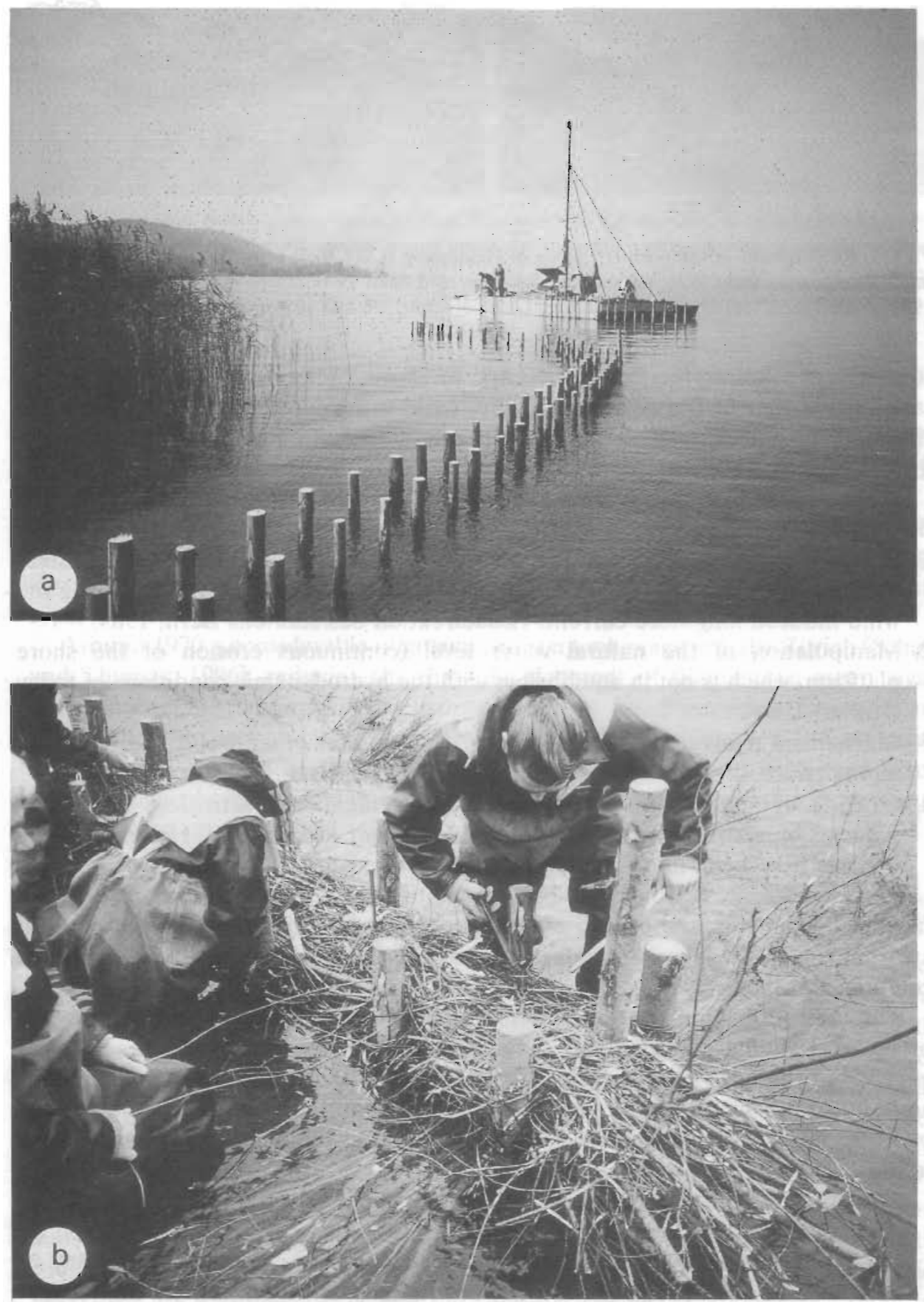

Fig. 12. Erection of a brushwood fascine: (a) piles rammed into the sediment; (b) mounting and fixing the brushwood. 
between two pile rows (Fig. 12). The work began in 1989 at the shore sections of highest ecological importance, and will be continued.

3. Scientific surveillance: the long-term development of the reeds is verified by aerial photographs, and short-term changes are recorded with field observations. The program is designed to take a second look at the conceptual ideas, and to avoid misinvestments.

4. Public relations: regular information about the state of affairs intends to create public awareness for the necessity to protect the endangered riparian landscape. The protection and restoration of lake shores is a complex and interdisciplinary responsibility. At Lake Biel this task is taken on by the Verein Bielerseeschutz (Society for the Protection of Lake Biel) in cooperation with the cantonal departments for regional planning, natural conservation and underground workings.

\subsection{Lake Neuchâtel, Grande Cariçaie}

Lake Neuchâtel is a mesotrophic lake of which the level of nitrate (ca. $1 \mathrm{mg} \mathrm{l}^{-1}$ ) is increasing constantly. The level of phosphate, having reached $50 \mu \mathrm{g} \mathrm{I}^{-1}$ in 1982 , has been decreasing thanks to water-purifying measures. The lake is oriented in the direction of the prevailing winds.

At the foot of a $35 \mathrm{~km}$ long steep sandstone slope at the eastern shore extends the largest marshland in Switzerland, the Grande Cariçaie, a wildlife reserve of international importance. The marshland grows on a bed of fine sand formed from the sandstone and slopes gradually over $300 \mathrm{~m}$ or even $1 \mathrm{~km}$ below the water level of the lake (Fig. 13). The origin of the Grande Cariçaie (named after its principal vegetative element Carex elata All.) is artificial: around 1880, the level of the lake was lowered by $2.7 \mathrm{~m}$, whereupon half of the sandy bottom, $20 \mathrm{~km}^{2}$ emerged.

Until 1980 the only attention paid to the erosion of the shore was to its menacing effect on developed areas (harbours, buildings, silviculture). Since then management of the natural areas has been carried out systematically and the erosion studied in general (Roulier, 1980) The studies show an average erosion of $2 \mathrm{~m}$ annually for more than $10 \mathrm{~km}$, which amounts to a yearly loss of $2 \mathrm{ha}$. In many sites the shore is clearly set off by a rim of sand in the form of small dunes sprouting shrubs or reeds.

A recent study has made clear that this erosion is inevitable (Huber, 1989). Given the unstable condition created by the artificial lowering of the water level, the bottom of the lake has been undergoing change for a century already. Situated as it is on the axis of dominant wind currents the lake is a significant fetch, with waves as big as $2 \mathrm{~m}$ high.

Lacking a cohesive element, the fine sandy soil of the marshland offers no resistance: sand up to $6 \mathrm{~m}$ in depth will give way in average conditions (5 hours of wind at $27 \mathrm{~km}$ per hour for a fetch of $35 \mathrm{~km}$ ). Thus during several days each year erosion takes place over $20 \mathrm{~km}^{2}$ of the littoral; the shallow water zone sweeps in its currents hundreds of thousands of cubic metres of sand to the depths.

Since its creation a century ago, half of the newly formed land surface has been eroded. The decline of the reed beds, which has been noticed in several places 


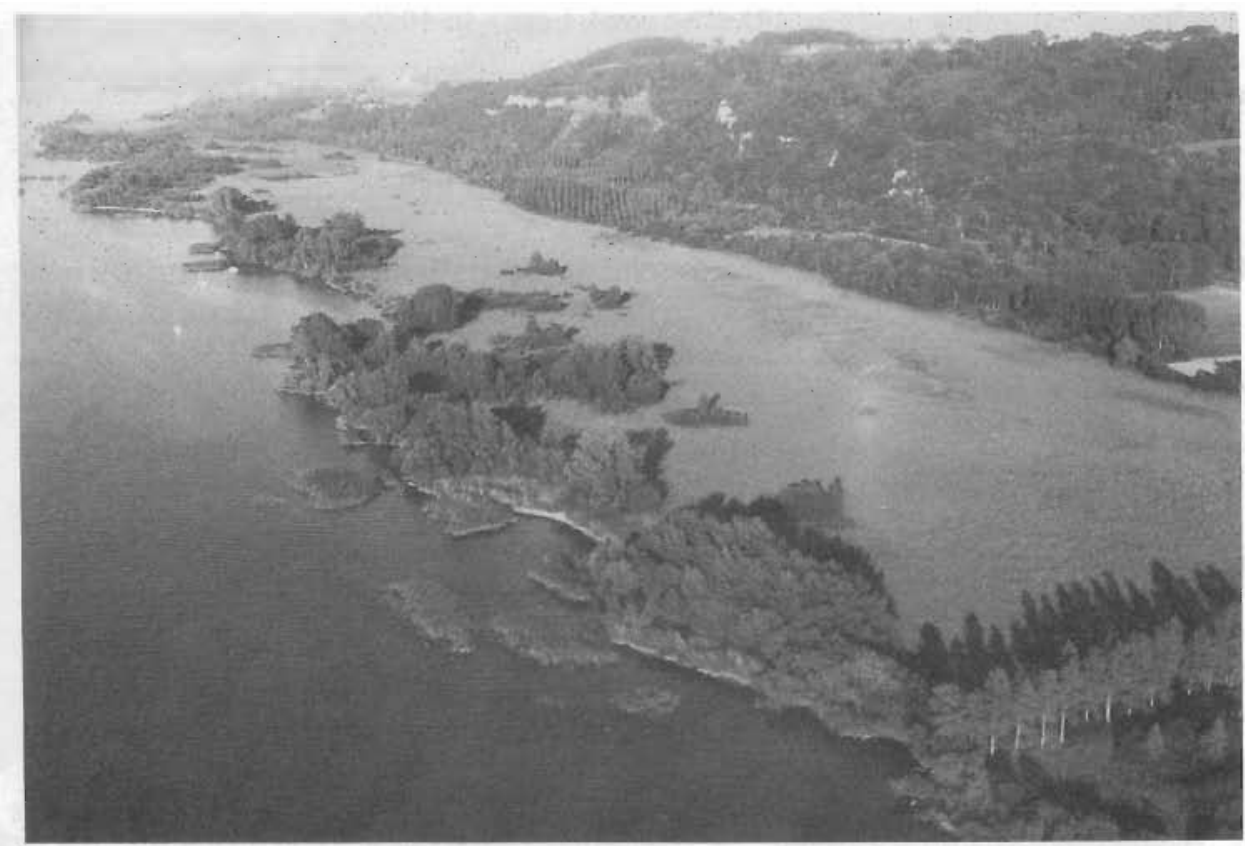

Fig. 13. After lowering the level of Lake Neuchâtel in 1880 half of the shallow water zone emerged; another $20 \mathrm{~km}^{2}$ remained under less than $3 \mathrm{~m}$ water.

without being actually studied as such, is not the principal phenomenon. It is not erosion of the shore but the overall washing away of the sand bed that is at stake (Fig. 14). Understandably no vegetation, regardless of its stabilising force (reed, alder, or willow) will withstand the ground disappearing from beneath it. According to the above-mentioned report this erosion will continue until the lake is confronted with a solid obstacle.

Not only has the erosion been studied, but several conservation attempts have also been undertaken to try to find a solution adaptable to such a rockless terrain. During the last six years three different types of structures have been constructed along five sections varying between $150 \mathrm{~m}$ and $300 \mathrm{~m}$ in length. The most satisfactory means to date has been stacking wooden spikes perpendicular to the shoreline. This cage of wooden poles is then filled in with large stones. The surface of the whole structure is covered with a geo-textile (mineral-fibre cloth) on which is laid a layer of sand that is planted with willow sprouts (Fig. 15). Before adapting this method as a solution, its capacity to hold back the displacement of sand must be proven. The cost of the construction does not mean very much: given that this is a trial, the work has been carried out with the help of State services, volunteers, and the Army. The expenses then do not reflect the actual cost for such construction executed on a large scale by a contractor.

Research will continue on the scientific level by a study of the role of reed beds and on the technical level by a mapping of $20 \mathrm{~km}^{2}$ of the shallow water zone. 


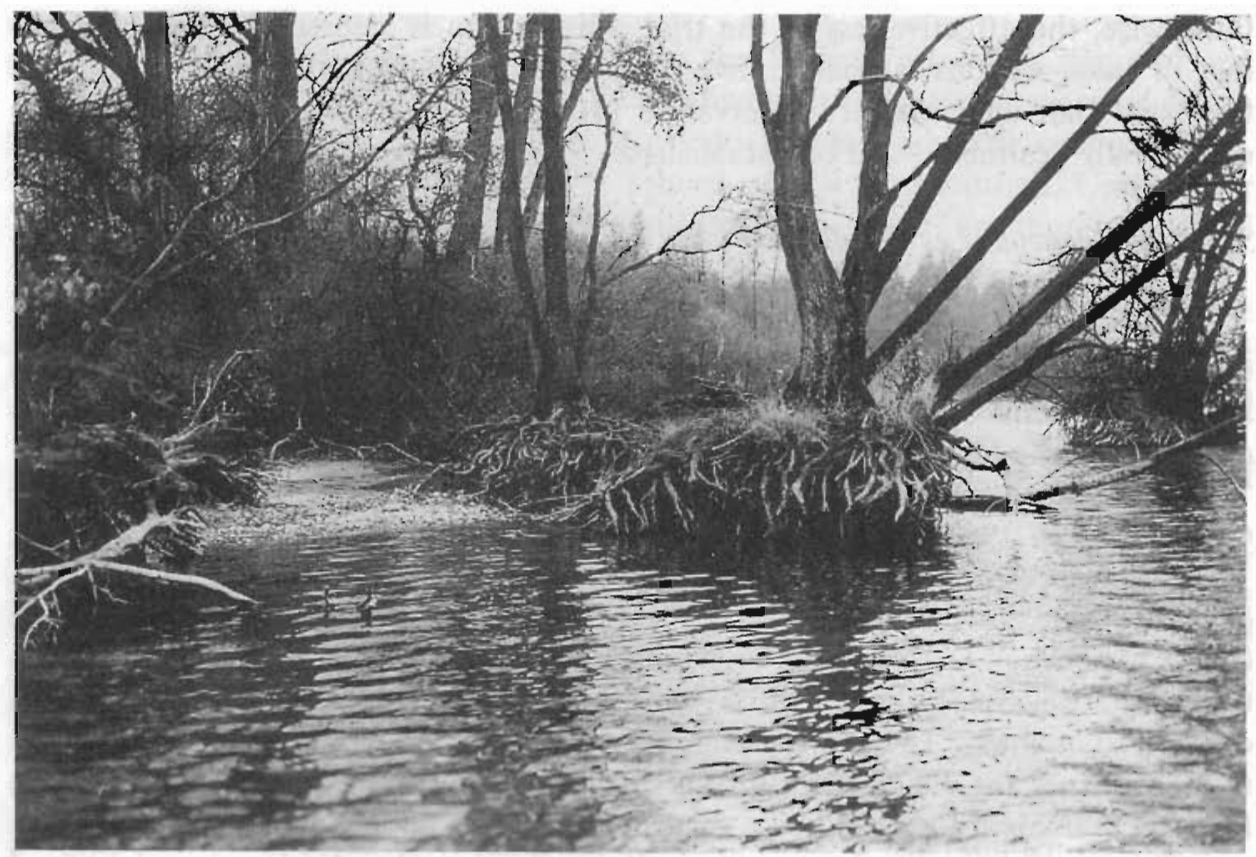

Fig. 14. While the waves wash the sand away, the ground disappears; no alder or other plant is able to withstand it.

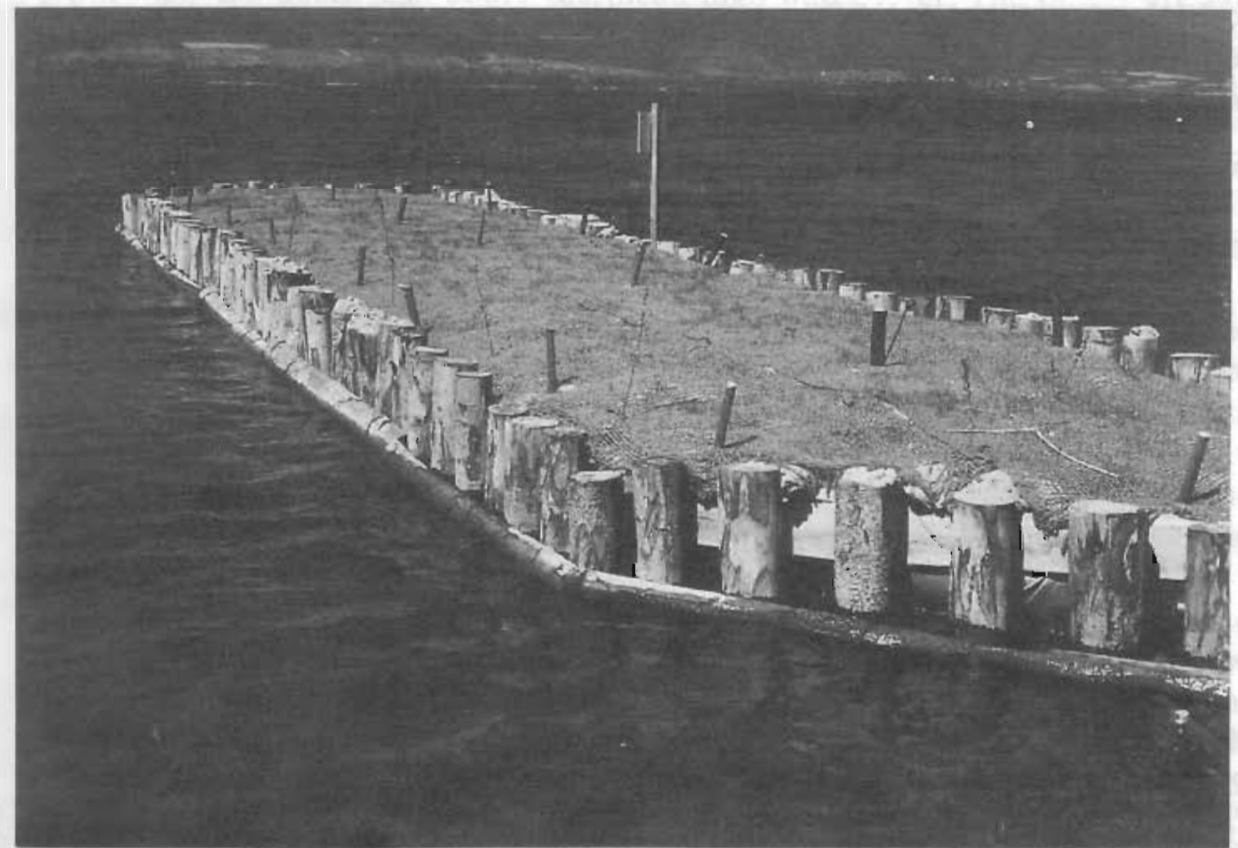

Fig. 15. The cage of poles is filled first with stones, then with sand, and planted with willow sprouts. 
Otherwise, the effectiveness of the trial construction is assessed by regular readings of cross-sections in comparative sectors with and without structures. It is on this basis that an eventual conservation project - to the extent that it would be ecologically desirable -will be established.

\subsection{Lake Geneva, Les Grangettes}

The shores of Lake Geneva, on an important part of the periphery, are very steep and rocky. They are, generally, not favourable for the development of a wide riparian vegetation. However, the region of the Grangettes at the southeastern extremity of the lake, silted up by the Rhône delta, is an exception.

In 1942 the lacustrine reed-belt covered 17 ha $(=5 \mathrm{~km}$ of shoreline) of the Grangettes. In 1982, only 3 ha along $1.5 \mathrm{~km}$ of the shoreline remained (Moret, 1982). The recession propagates from west to east: between 1942 and 1972, a zone of $50 \mathrm{~m}$ width vanished in the western part. Towards the east the retreat reached ca. $5.8 \mathrm{~m}$ between October 1976 and June 1979 (Moret, 1980). The decline went on until 1987-88. Since then, a little improvement has been observed, but is still difficult to quantify. The shore topography has also been modified, as the reedbelt retreated from the submerged littoral to semiaquatic shore. The material eroded from the bank is transported by a longshore current produced by the Rhône from west to east. The suspended matter settles near obstacles, leading to a lakeward shifting of the shoreline at some sites.

The causes of the shore retreat and of the reed decline are thought to be multiple. A comparison of the general conditions prevailing in the first half of the century -at a time when reed-stands were very abundant -and at present points out four essential alterations (Fig. 16):

A

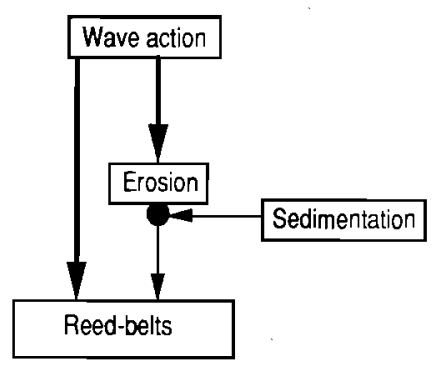

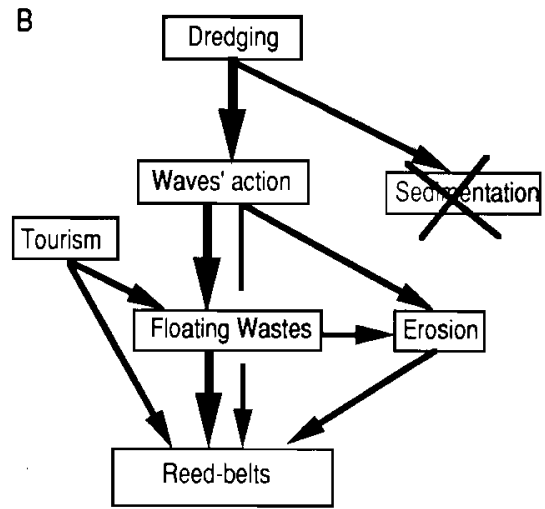

Fig. 16. Change of factors influencing the dynamic development of the reed belt. (a) In the first half of the century: the development of the lake shore vegetation depends on direct wave action, and local erosion which is compensated for by sediment input. (b) In the years after ca. 1950: increase of detrimental factors (gravel exploitation, recreational activities, floating wastes) which inhibit nearshore sedimentation, enhance overall erosion and mechanical stress to the reeds. 
1. Drifting matter -mainly dead wood from the Rhône river -was removed and used as fuel before 1940-50. Until 1975, when countermeasures were taken, an estimated volume of $1550 \mathrm{~m}^{3}$ of waste wood was washed ashore each year.

2. The gravel exploitation in the lower littoral zone was intensified. Underwater gravel pits reduce the width of the shoal littoral; the waves are thereby allowed to reach the shoreline with their whole energy.

3. The underwater gravel pits in the channel of the River Rhône have reduced the bedload transport to the littoral zone to compensate for the bank erosion. The imbalance is aggravated by the presence of offshore dragging trenches which catch the little material the river has transported.

4. The increase of recreational activities has been harmful to the reeds because of trampling and by pleasure boat traffic.

As suggested by the work of Lachavanne et al. (1974), the Ligue vaudoise pour la Protection de la Nature (League for the Protection of the Natural Environment in the Canton Vaud) and the government of the Canton Vaud set up several countermeasures designed to stop bank erosion and reed retreat and to restore damaged sites:

1. Moving the borderline of underwater dredging offshore to create a littoral zone broad enough to dissipate the wave energy by bottom friction.

2. Construction of breakwater dams ca. $100 \mathrm{~m}$ in front of the reed fringe (Fig. 17). Up to now, dams totalling more than $1500 \mathrm{~m}$ in length have been constructed, financed by the cantonal government. Some of these dams are ca. $100 \mathrm{~m}$ long, with their top about $1 \mathrm{~m}$ above the mean high water level. The others are not higher than the mean high water level and are interrupted by gaps at distances of $10 \mathrm{~m}$, allowing wave-induced currents to penetrate and to refresh the backwater. However, the constructions are hollowed out from below by the breakers and sink into in the fine grained ground. Hence, they must be raised occasionally.

3. Prohibition of trespass in the more important sites of riparian vegetation and of navigation nearby these sites.

4. Installation of a floating barrier at the mouth of the River Rhône, to check the dead wood and the wastes brought in by the river. The efficiency is not great -about $1000 \mathrm{~m}^{3}$ (i.e. 400 tons) of matter are yielded annually. Moreover, each year, during two weekends in spring, when the lake level is low, volunteers clean the shore of the Grangettes. In 1989, 200 tons of debris were removed from the reedbelt and were flown out by a helicopter to avoid further mechanical damage.

5. Plantations of reed at former sites. Beginning in 1981, the work was conducted by volunteers, and subsequently supported by the Canton of Vaud. In the sheltered shore section, without erosion and frequently cleaned, the plantations succeeded: from 3 groups with 10 balls of earth and rhizomes of $50 \times 50 \times 30$ $\mathrm{cm}$ each, a reed-stand of nearly $1000 \mathrm{~m}^{2}$ developed. However, in the more exposed sites the results were negative: the plantations did not take root, the stems were destroyed by the floating matter, or simply disappeared after a few years of development. 


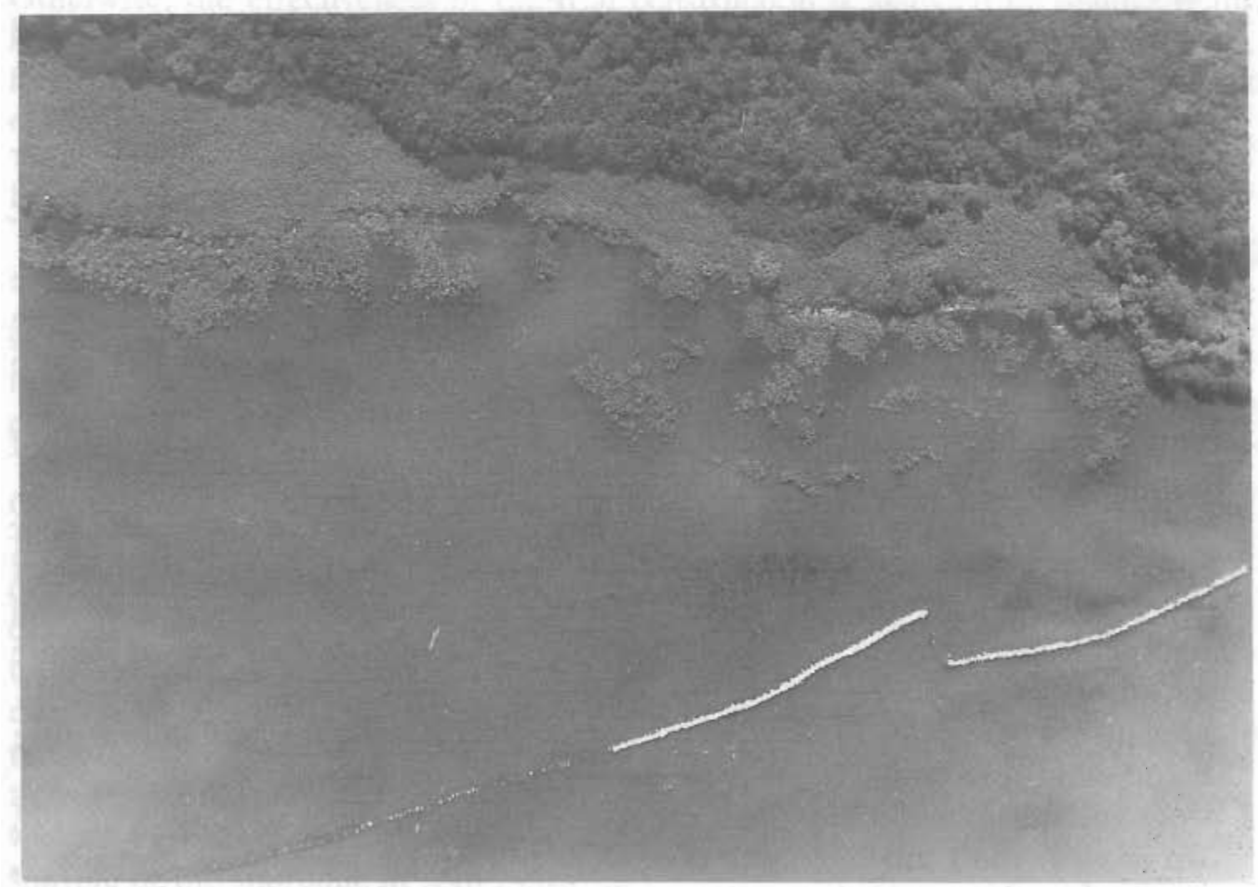

Fig. 17. Two types of breakwater dams in front of the damaged reed front. Left: dams with their top $\sim 1$ metre above the mean high water level. Right: dams with their top on a level with the mean high water: ihe dams adjusted approximately parallel to the wave crests.

Besides this, other projects are in preparation. They aim to prevent progressive erosion by creating new sediments:

1. An artificial lagoon is to be created in front of a heavily eroded shore by prolonging an existing breakwater dam by $100 \mathrm{~m}$, and by constructing a new dam perpendicular to the shore. This protected zone should form a sink for suspended silt and bediload sand formerly washed away by the littoral currents. A new bed for the development of a riparian vegetation should therefore be created.

2. An additional amount of sediment is to be deposited in the nearshore zone by using the spoil from the sublittoral gravel dragging. It is assumed that the waves and currents will spread them along the shore in a 'natural' way, thereby preventing progressive erosion.

In June 1990, the 'Grangettes' was registered as an object of the Ramsar convention, i.e., a wildlife reserve of supra-national importance. As a consequence, new management structures for protection and maintenance have been established. This will give a new impulse to shore protection measures which have become a little neglected over the last five years. 


\section{Conclusions}

In respect of the factors which create the 'die-back' of reeds and related lakeshore vegetation, the above examples from seven lakes exhibit a wide range of possible causes. There are, however, three main groups of factors: (a) the enhanced nutrient level in the lake, (b) the mechanical damage to the reeds, which in turn can be traced back to ship-induced waves, cultural debris, algal wash, and trampling by holiday-makers, and (c) bank erosion together with lake level manipulations. All these factors are specific aspects of human impact to lakeshores.

The kind of protection and shore restoration chosen depends on (a) the main factor(s) which have been made responsible, (b) the idea of a 'natural' or a 'extensively interfered' or a 'pre-industrial' riparian scenery that is to be restored, and (c) the technical possibilities and the maximum expenditure of money.

The eutrophication factor implies greater efforts in waste water purification measures, or, as it was attempted at Lake Constance-Untersee, in the removal of nutrients from the reeds by winter mowing and clearing of mud. However, the attempts failed with respect to these latter objectives. Furthermore, the concept of reed decline due to eutrophication has been criticized by Ostendorp (1990a), who concluded that until now there is no clear-cut evidence for this hypothesis. Hence, most protection and maintenance works are restricted to controlling mechanical damage and bank erosion.

The enhanced bank erosion seems to be correlated with lake level manipulations, as was evidenced by Huber (1989) at Lake Neuchâtel. The change of littoral topography due to altered wave forces which in turn results from lake level changes is lingering and unpredictable, and no simple prescription is evident to stop these processes. The demand to re-establish the pre-industrial lake level is unrealistic. Therefore countermeasures are concentrated on the most endangered shore sections. There is some evidence that solid constructions like walls, pile planking and stone dams at the shoreline will intensify bank erosion by reflecting wave energy to the unprotected floor and by accelerating and channelling the littoral currents.

Hence, the overall aim of protection or restoration measures is to create dissipative conditions in the littoral zone, lowering breaker energy and littoral sediment transport. Some examples have been presented in the foregoing text. It will require lengthy field research and discussion to discover a procedure which optimises costs, employment of labour, and the 'naturalness' of the construction with respect to well-defined aims of restoration. For the time being, favourable issues counterbalance undesired results.

In some cases waterway authorities try to mask land reclamations and raisings, and solid shore-protecting buildings with a more natural construction. The design of the constructions is often based only upon the individual perception of how a natural shoreline should appear. Ultimately, arguments of technical practicability and of expenditure of money make all the difference. Actually there are no generally accepted criteria for the 'naturalness' of a shore section, and how to restore it. A proposal coming from the experiences at Lake Constance has been 
made by Ostendorp and Krumscheid-Plankert (1990). The authors insist that lakeshore restoration works should include keeping out promenaders, anglers, surfers and boats in a wide periphery.

At the moment, the scientific foundations of many restoration works are weak. There is a need for fundamental research on the dynamics of littoral bottom sediments and littoral vegetation under natural conditions as well as following human-induced change of the sedimentation-erosion equilibrium.

\section{Acknowledgements}

We are indebted to John S. Turrell for linguistic comments.

\section{References}

Baudirektion des Kantons Bern (ed.), 1989. Naturnahe Flachufer an Seen -Maßnahmen zu ihrer Erhaltung und Wiederherstellung. 97 pp. + app., Berne (Switzerland).

Bertschi, H., 1952. Die Zürichseeregulierung. Wasser-, Energiewirtschaft, 10/11: 1-16.

Burnand, J., 1979. Das Röhricht am Zürcher Ufer des Zürichsees: Entwicklung, heutiger Zustand, Aussichten. Report of the Beratungsgemeinschaft für Umweltfragen, Zürich, $34 \mathrm{pp}$. (source of supply: Amt für Gewässerschutz und Wasserbau des Kantons Zürich, Walchetor, CH-8090 Zürich, Switzerland).

Burnand, J. and M. Küper, 1988. Röhricht am Zürcher Ufer des Zürichsees. Report of the Beratungsgemeinschaft für Umweltfragen, Zürich, $8 \mathrm{pp}$. (source of supply: see above).

Egloff, F., 1977. Wasserpflanzen des Kantons Zürich. Vierteljahrsschrift der naturforschenden Gesellschaft Zürich, 122: 140 pp.

Hagenmeyer, T. and P. Krumscheid-Plankert, 1990. Bericht zur Dynamik und Schädigung der Schilfgebiete im Bodenseekreis. Report for the Landratsamt Bodenseekreis, Umweltschutzamt, 109 pp. (source of supply: Landratsamt Bodenseekreis, D-88045 Friedrichshafen, Germany).

Huber, A., 1989. Erosion am Südufer des Neuenburger Sees. Expertise of the Versuchsanstalt für Wasserbau, Hydrologie und Glaziologie der ETH Zürich for the Groupe d'étude et de gestion, Champ-Pittet (Yverdon), Zürich, 60 pp.

Iseli, C., 1990. Die Geschichte der Schilfröhrichte am Bieler See und Folgerungen für den praktischen Schilfschutz. In: H. Sukopp and M. Krauss, (Eds.), Ökologie, Gefährdung und Schutz von Röhrichtpflanzen. Landschaftsentwicklung und Umweltforschung (Berlin), 71: 212-228.

Iseli, C. and T. Imhof, 1987. Bieler See 1987 - Schilfschutz, Erhaltung und Förderung der Naturufer. Schriftenreihe des Vereins Bielerseeschutz, 2: 151 pp.

Klötzli, F., 1974. Über Belastbarkeit und Produktion in Schilfröhrichten. Verhandlungen der Gesellschaft für Ökologie (Saarbrücken) 1973, pp. 237-247.

Krauss, M., 1979. Zur Nahrungsökologie des Bläßhuhns Fulica atra auf den Berliner Havelseen und der Einfluß von Bläßhuhn und Bisamratte Ondatra zibethicus auf das Schilf Phragmites communis. Anzeiger der Ornithologischen Gesellschaft Bayern, 18: 105-144.

Krauss, M., 1990. Die Nahrung des Bisams (Ondatra zibethicus) an der Havel in Berlin (West) und der schädigende Einfluß auf das Röhricht. In: H. Sukopp and M. Krauss (Eds.), Ökologie, Gefährdung und Schutz von Röhrichtpflanzen. Landschaftsentw. Umweltforsch. (Berlin), 71: 141-181.

Krumscheid, P., H. Stark and M. Peintinger, 1989. Decline of reed at Lake Constance (Obersee) since 1967 based on interpretations of aerial photographs. Aquatic Botany, 35: 57-62.

Krumscheid-Plankert, P., 1992. Ufersanierung und Röhrichtschutz -Abschlußbericht zum Entwicklungsund Erprobungsvorhaben 'Wiederansiedlung von Schilfbeständen am Bodensee' für das Bun- 
desministerium für Umwelt, Naturschutz und Reaktorsicherheit. Report of Limnologisches Institut, Universität Konstanz, Vol. 2, 117 pp. + 91 Fig.

Lachavanne, J.-B., C. Choulat and A. Munteanu, 1974. Evolution de la basse plaine du Rhône, objet naturel d'importance nationale. Bulletin technique de la Suisse romande No. 18 (1975), No. 1 (1976).

Lachavanne, J.-B. and J. Perfetta, 1985. Les macrophytes du Lac de Zurich. Beitr. geobot. Landesaufn. Schweiz, 61: 78 pp.

Lüdi, W., 1935. Das Grosse Moos im westschweizerischen Seelande und die Geschichte seiner Entstehung. Veröff. Geobot. Inst. Rübel Zürich 11, 344 pp. + app.

Moret, J.-L., 1980. Les Grangettes (Objet naturel d'importance nationale IFP No. 15.02, KLN No. 3.16). A propos de la régression des roselères. Report for the Ligue suisse pour la protection de la nature, $91 \mathrm{pp}$.

Moret, J.-L., 1982. Evolution des roselières lacustres de la région des Grangettes entre 1976 et 1982. Bulletin de la Societé vaudoise des Sciences naturelles, 76 (2): 185-195.

Oberli, A., 1990. Die Wild-Karte des Kantons Zürich 1852-1868. Dokumentation zur Faksimilierung. Meliorations-und Vermessungsamt des Kantons Zürich, 16 pp., Zürich.

Ostendorp, W., 1987. Die Auswirkungen von Mahd und Brand auf die Ufer-Schilfbestände des Bodensee-Untersees. Natur und Landschaft, 62: 99-102.

Ostendorp, W., 1989. 'Die-back' of reeds in Europe -a critical review of literature. Aquatic Botany, 35: $5-26$.

Ostendorp, W., 1990a. Ist die Eutrophierung am Schilfsterben schuld? In: Sukopp, H. and Krauss, M.K. (Eds), Ökologie, Gefährdung und Schutz von Röhrichtpflanzen. Landschaftsentwicklung und Umweltforschung (Berlin), 71: 123-140.

Ostendorp, W., 1990b. Die Ursachen des Röhrichtrückgangs am Bodensee-Untersee. Carolinea, 48: 85-102.

Ostendorp, W. and P. Krumscheid-Plankert, 1990. Röhrichtschutz und Uferrenaturierung am Bodensee. Gas-und Wasserfach/Wasser, Abwasser, 131: 78-84.

Pier, A., M. Dienst and H. Stark, 1990. Die Dynamik der Schilffront am Bodensee-Untersee. In: Sukopp, H., Krauss, M.K. (Eds), Ökologie, Gefährdung und Schutz von Röhrichtpflanzen. Landschaftsentwicklung und Umweltforschung (Berlin), 71: 78-85.

Rebsamen, H.P., R. Schilling and E. Liniger, 1975. Zürichseeufer 75. Stäfa, 175 pp.

Roulier, C., 1980. Etude préliminaire de l'érosion de la rive sud du lac de Neuchâtel. Report of the Groupe de travail rives du lac de Neuchâtel, 21 pp. + app.

Schanz, F., 1974. Gibt es am Zürichsee noch schützenswerte Wasserpflanzen? Vierteljahrsschrift der naturforschenden Gesellschaft Zürich, 119: 349-359.

Schanz, F., 1979. Blütenpflanzen und Algen der Seeufer. In: Coigny, D. (Ed.), Der Zürichsee und seine Nachbarseen, pp. 87-112.

Schanz, F., 1980. Die Entwicklung von Schilfbeständen am unteren Zürichsee 1979/80 in Beispielen. Vierteljahrsschrift der naturforschenden Gesellschaft Zürich, 125: 393-406.

Schanz, F. and E.A. Thomas, 1986. Der Zürichsee, Beispiel für einen Oligotrophierungserfolg durch externe Maßnahmen. In: H. Sukopp and M. Krauss (Eds.), Ökologie, Gefährdung und Schutz von Röhrichtpflanzen. Landschaftsentw. Umweltforsch. (Berlin), 70: 531-540.

Schiess, H., 1978. Gedanken zum Naturschutz an Zürich-und Obersee. Verband zum Schutze des Landschaftsbildes am Zürichsee, Jahresber., 52: 11-37.

Schröder, R., 1979. The decline of reed swamps in Lake Constance. Symp. Biol. Hung., 19: 43-48.

Schröder, R., 1987. Schilfsterben am Bodensee-Untersee. Beobachtungen, Untersuchungen und Gegenmaßnahmen. Archiv für Hydrobiologie, Supplementum 76: 53-99.

Sukopp, H. and B. Markstein, 1989. Die Vegetation der Berliner Havel. Bestandsveränderungen 1962-1987. Landschaftsentwicklung und Umweltforschung (Berlin), 64: 1-128.

Thomas, E.A., 1965. Der Verlauf der Eutrophierung des Zürichsees. Mitteilungen der Österreichischen Sanitätsverwaltung, 66 (5): 3-12.

Wöbbecke, K. and W. Ripl, 1990. Untersuchungen zum Röhrichtrückgang an der Berliner Havel. In: H. Sukopp and M. Krauss (Eds.), Ökologie, Gefährdung und Schutz von Röhrichtpflanzen. Landschaftsentwicklung und Umweltforschung (Berlin), 71: 94-102. 